\title{
STUDY OF EXOTHERMIC WELDED JOINT GRINDING BY "SPENO" RAIL GRINDERS
}

\author{
Pavel Gavrilov, Viktor Ivanov \\ Riga Technical University, Latvia \\ pavels.gavrilovs@rtu.lv, viktori4301187@inbox.lv
}

\begin{abstract}
Exothermic welding joint is one of most common welded joints used in Europe. Latvian railway also uses exothermic welding for its rails in crossing pieces, station and railroad haul sections. Rail grinders are used to extend lifespan and maintain the tread surface of the rail's head and to remove and eliminate defects in the surface layer and to reduce corrugated rail wear. Rail grinders supplied by the company "Speno" are used in Latvian railways. This article will discuss the quality of grinding of exothermic welding joint of rail profile 60 E1 by "Speno" rail grinder. The research also includes analysis of ground rails in the Latvian railway during 2014, 2015, 2016, 2017 and 2018. First, detailed hardness of metal has been determined: on the tread surface, head, web and base, according to the Brinell scale by using the modern equipment "Tinius O Olsen" Fikrmware Version 1.07, FH-31 Series. Second, the chemical composition of an exothermic welding joint of rail steel (in head, web, base) has been examined with the optical emission spectrometer "ARC-MET 8000 Mobile Lab". The obtained data have been compared to standard technical documentation provided by the manufacturer. And third, in the final stage of the study, the structure of the exothermic welding joint of rail steel was determined and the main conclusions drawn concerning the quality of grinding and its impact on exothermic welding joints of rail profile $60 \mathrm{E} 1$.
\end{abstract}

Keywords: thermite, head, web, base, grade.

\section{Introduction}

Latvian Railways is one of the largest companies in Latvia, and a key player of the transport system of our country. Rails and their joints are the most valuable and responsible elements of the railway, since their condition firstly influences uninterrupted and safe movement of trains [1]. Thermic welding of rails means welding of two rails together by pouring molten metal over them. In this method of welding the metal is heated up with a thermite, consisting of powder mixture of metallic aluminium or magnesium and mill scale. In case of alumino-thermic welding the details to be joined together are moulded with a fire-proof material, heated up in the welding area, the liquefied thermite, which is ignited beforehand (with electric arc or igniter), is poured in the area of welding. The liquid metal, fusing together with the main metal, makes a durable joint. It is a common practice in the Latvian railway to weld point elements into a single structure to ensure an uninterrupted rolling of pair of wheels with the only exception being end-to-end structures as well as welding of rail bars.

During our study in Jelgava branch CDN-8 we cut out an exothermic welding joint from a rail profile $60 \mathrm{E} 1 \mathrm{~T}$ IV from the 1st main track in station Taurkalne $240 \mathrm{~km} 9 \mathrm{rmp}$. within the routine maintenance of the track. On 22.08.2015, the said exothermic welding joint was ground with a "Speno" rail grinder. Currently the company "Speno International SA" is the leader of rail grinding on railways. This company particularly offered the technology of rail processing according to the surface grinding with the lace of a cup wheel pattern. This method started to gain popularity in Latvia in mid 2000s, when the rail grinder URR-112 (Fig. 1), supplied by the Swiss company "Speno", started to operate on Latvian railways. Total length of tracks of SJSC "Latvian Railways" reaches $3.017 \mathrm{~km}$ and only $258.8 \mathrm{~km}$ of them have been electrified, therefore, for the purposes of efficient use of resources, Latvian Railways rents a rail grinder, type UR-48, from the company SPENO. Grinding of rails takes place after laying of new rails or after 200-250 million tonnes of gross weight as per the European standard EN 13231-3:2012 [2].

A list of rail defects to be removed by grinding with said technology is rather general and includes: corrugated rail wear, mechanical damage, crushing and exfoliation of metal. Therefore, one of the main goals of grinding is reprofiling of transverse rail profile. Periodical corrections of the profile by means of grinding ensure the best contact of the wheels with a rail, equal distribution of internal load across the rail surface and at the same time prolong the lifespan by $15-20 \%$ [2]. According to standard technical documents, accuracy of transverse rail profile to be ground and surface undulation are the main criteria laying down the quality reference points for rail grinding 
works. Transverse rail profile is shaped with several abrasive tools that work concurrently according to the surface grinding with the lace of a cup wheel pattern.

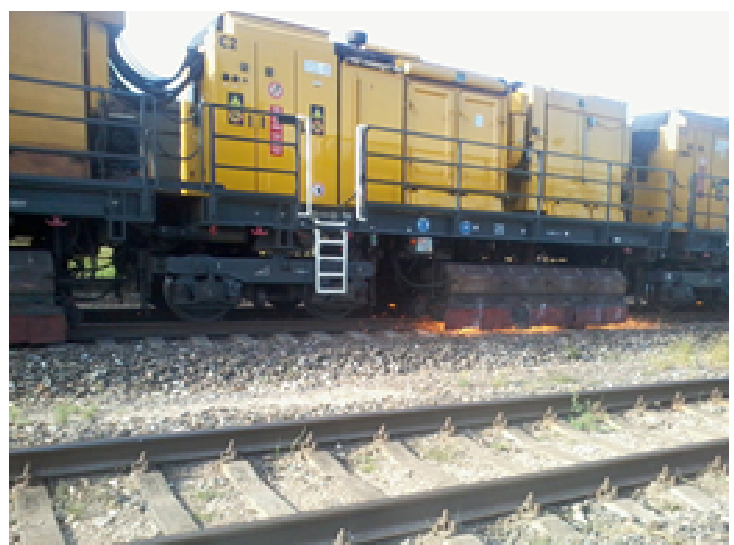

Fig. 1. Grinding of 1st main track in station Taurkalne with "Speno" rail grinder

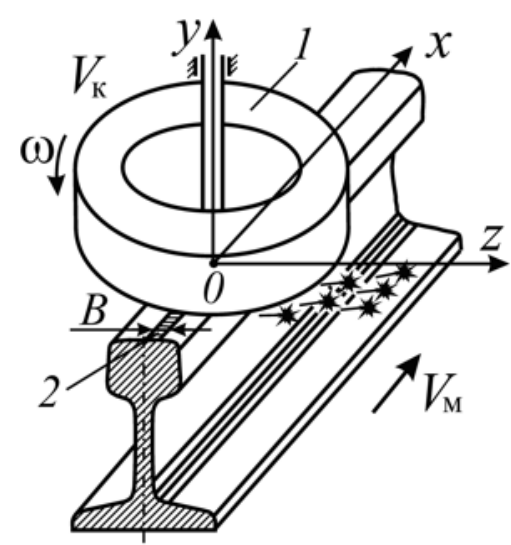

Fig. 2. Rail grinding pattern: 1 - abrasive wheel; 2 - area of metal grinding

Profile grinding of the rail head of the track is done due to abrasive processing with rotating wheels (Fig. 2) by the "track" method of the lace of the cup wheel. The abrasive wheel 1 rotates around the OY axis and removes a strip of metal 2 from the rail at the width of B, giving the transverse motion of the mechanism along the rail [3]. For a comparison, in railways of the USA, having a huge working capacity, the rails are ground to remove fatigue cracks and to have rail heads profiled. Besides, the frequency of grinding works is determined by 20 to 40 millon tonnes gross in curved tracks with small and average radiuses and 40 to 80 millon tonnes gross in curved tracks with a large radius and on the straight sections of the track. On English and French railways grinding of rails is divided into: grinding of new rails after they are laid in to remove the factory defects; planned and preventive grinding allowing to remove defects that consequently lead to micro cracks; grinding to repair and restore through profiling of the rail head. Besides rail grinding works are done at the speed of $1-2 \mathrm{~km} \cdot \mathrm{h}^{-1}$ in case of the cutting depth of $0.1-0.4 \mathrm{~mm} \cdot \mathrm{step}^{-1}$ [4]. Federal railways in Germany are mainly ground to remove short-pit corrugations on the high-speed sections of the track.

After grinding of rails joined with an exothermic welding in our case, the first question arises is it necessary to grind rails and their joints and has the grinding been performed at good quality? The second question leads us to find out how the given process influences the condition of an exothermic welding joint in terms of hardness, chemical composition and how to determine the structure of metal?

To fully evaluate efficiency of operation of the Speno rail grinder on the Latvian railways and individual sections, let us set up a statistical diagram (Fig. 3) of rails ground by the Speno rail grinder between 2014 and 2018.

It follows from the diagram in Fig. 3 that in 2014 the majority of rail grinding took place in CDN3 Daugavpils branch $60.82 \mathrm{~km}$. tracks, in CDN-1 Skirotava branch it totalled in $58.676 \mathrm{~km}$ of track, in CDN-8 Jelgava branch $40.40 \mathrm{~km}$ of track were ground, while in CDN-2 Ciekurkalns track $34.90 \mathrm{~km}$ of track were ground. In CDN-5 Rezekne branch $12.852 \mathrm{~km}$ of track and in CDN-9 Riga branch $10.850 \mathrm{~km}$ of track were ground.

No rails were ground in CDN-6 Ventspils branch and CDN-7 Liepaja branch.

In 2015, the largest section of rails in terms of kilometres were ground in CDN-5 Rezekne branch amounting to $55.10 \mathrm{~km}$ of track, followed by CDN-3 Daugavpils branch totalling in $53.94 \mathrm{~km}$ of track. In CDN-2 Ciekurkalns branch - $40.00 \mathrm{~km}$ of track and in CDN-8 Jelgava branch - $29.50 \mathrm{~km}$ of ground rails. CDN-6 Ventspils branch $19.91 \mathrm{~km}$ of track and in 2015 the least length in terms of kilometres was ground in CDN-1 Skirotava branch $-4.80 \mathrm{~km}$. No rail grinding took place in CDN-9 Riga branch and CDN-7 Liepaja branch.

CDN-3 Daugavpils branch had the longest section of rails ground in 2016, totalling in $63.50 \mathrm{~km}$ of track. The second place in terms of the amount of rail grinding work was taken by CDN-5 Rezekne branch with $45.27 \mathrm{~km}$ of track. CDN-2 Ciekurkalns branch took the third place, totalling in $29.933 \mathrm{~km}$ 
of track. CDN-8 Jelgava branch had $20.85 \mathrm{~km}$ of track, whereas the neighbouring CDN-6 Ventspils branch had $19.91 \mathrm{~km}$ of track ground. In CDN-9 Riga branch rails were ground only in $7.35 \mathrm{~m}$ of track, while in CDN-1 Skirotava branch $-4.80 \mathrm{~km}$ of track. In CDN-7 Liepaja branch, like in the previous years, the rails were not ground.

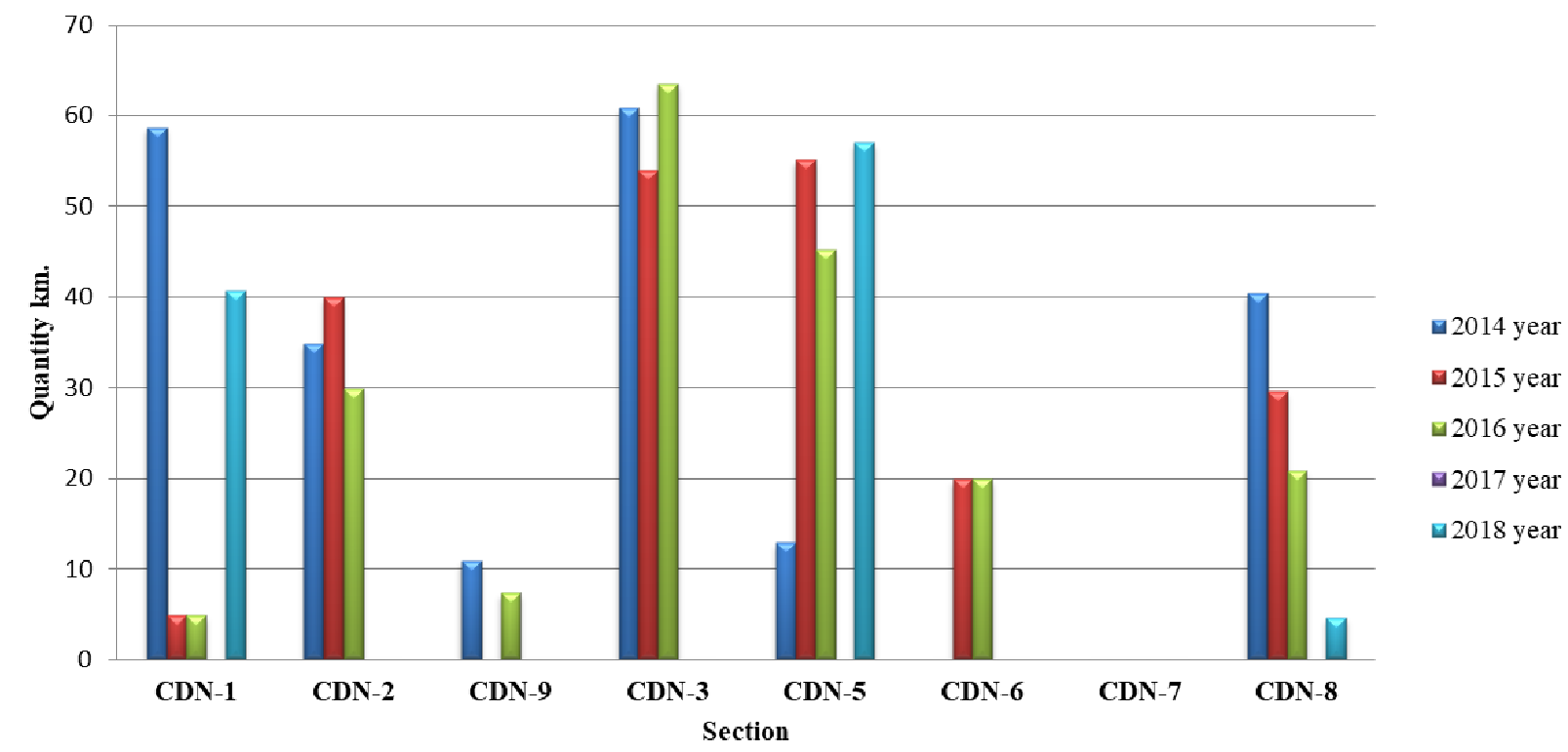

Fig. 3. Statistical diagram of rails ground by Speno rail grinder between 2014 and 2018 Latvian railway is divided into eight individual sections, out of them: CDN-1 Skirotava branch; CDN-2 Ciekurkalns branch; CDN-3 Daugavpils branch; CDN-9 Riga branch; CDN-5 Rezekne branch; CDN-6 Ventspils branch; CDN-7 Liepaja branch; CDN-8 Jelgava branch

The statistical diagram (Fig. 3) shows that in 2017 the rails of the Latvian railway were not ground.

In 2018 one can see a decrease in operation of the rail grinder in the railway branches, Fig. 3. Through an analysis one can arrive at a conclusion that in CDN-2 Ciekurkalns, CDN-9 Riga, CDN-3 Daugavpils, CDN-6 Ventspils and CDN-7 Liepaja branches the rails were not ground. In CDN-5 Rezekne branch the rails were ground in $57.00 \mathrm{~km}$ of track, in CDN-1 Skirotava branch $-40.65 \mathrm{~km}$ of track and the least length of the rail track was ground in CDN-8 Jelgava branch, totalling in 4.60 $\mathrm{km}$ of track.

The given statistical diagram once more evidences that in order to save economic resources and to have Latvian railway tracks [5] ground, in terms of number of kilometres, it is more efficient to order grinding of rails from foreign companies rather than own a grinder.

According to an updated instruction concerning rail defects, their indications, classification, catalogue, marking and conditions under which the trains can be allowed to drive on defective and highly

defective rails C-101 [6], within the schedules established by the permanent way inspector the condition of rail steel is inspected one time per month as a rule by using the sonic analyser RDM-23, RDM-24. Within the framework of our study we monitored the condition $240 \mathrm{~km} 9 \mathrm{rmp}$ of an exothermic welding joint before and after grinding performed by the rail grinder. Before grinding the exothermic welding joint, on the ridge of the rail head there were ground-swells as stratified metal and also fine cracks, uneven spots and rough edges under the impact of wheel pairs rolling over that could eventually lead to development of defects (under code 10.1-2, 11.1-2, 14, 17.1-2, 24) [7] in the head of the rails and further breakdown. After grinding of the exothermic welding joint, the mentioned defects were removed and examined with the sonic analyser RDM-23. Between 22.08.2015 and 30.05.2018 no defects were found in the exothermic welding joint. Consequently, it again justifies a need for grinding of rails and joints to prolong their lifespan and save resources otherwise spent on restoration. 


\section{Welding rail steel hardness tested}

During the first stage of the study in a lab of the Riga Technical University (Laboratorijas mājas) the exothermic welding joint of rail steel was thoroughly tested for hardness by the Brinell scale (HB) with a device "Tinius O Olsen" Fikrmware Version 1.07, FH - 31 Series. Procedure to determine the rail steel hardness was performed in line with the standards (ISO 6508, ISO 2039/1, ASTM E18, ASTM B254, JIS Z2245). The study results are shown in Fig. 4.

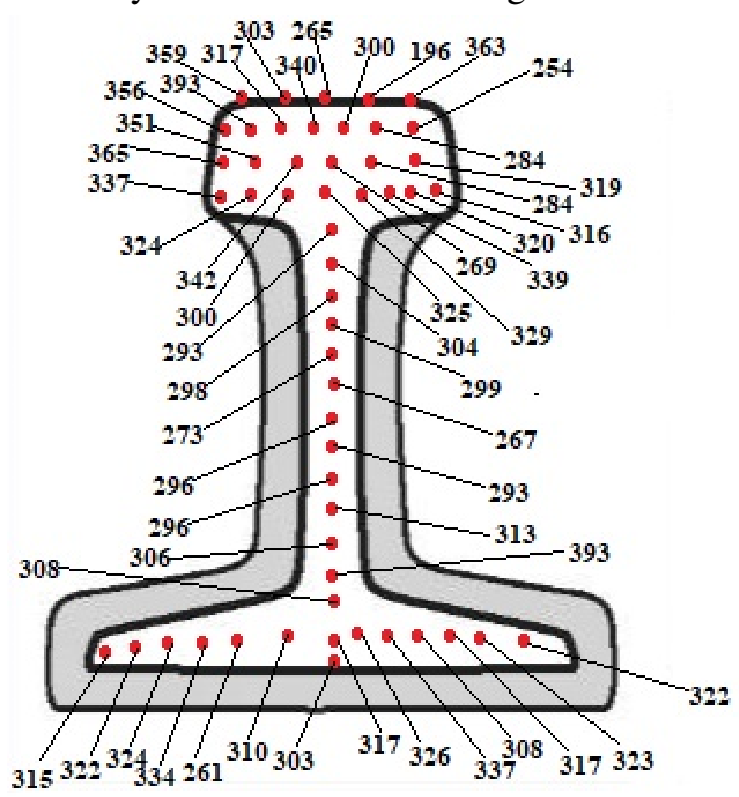

Fig. 4. Determination of hardness of ground exothermic welded joint in rail profile $60 \mathrm{E} 1 \mathrm{~T}$ IV

06 in HB: on the tread surface of the exothermic welded joint $(359,303,265,196,363)$;

in the head of the exothermic welded joint $(356,393,317,340,300,284,254,365,351,342,269$,

$284,319,337,324,300,325,329,339,320,316)$; in the web of the exothermic welded joint (293, $304,298,299,273,267,296,293,296,313,306,393,308)$; in the base of the exothermic welded joint $(315,322,324,334,261,310,326,337,308,317,323,322,317,303)$

On the basis of the received data a table was created and comparisons made against the passport data provided by the manufacturer. Comparison results are given in Table 1.

Table 1

\section{Comparison of hardness of ground exothermic welding joint 60 E1 T with steel grade R350HT}

\begin{tabular}{|c|c|c|}
\hline \multirow{2}{*}{ Area where hardness is tested } & \multicolumn{2}{|c|}{ Rail hardness grade R350HT } \\
\cline { 2 - 3 } & $\begin{array}{c}\text { Hardness (exothermic welding } \\
\text { joint in line with the } \\
\text { instruction C - 015 (HB) }\end{array}$ & $\begin{array}{c}\text { Average hardness } \\
\text { (exothermic welding } \\
\text { joint 60 E1 T) (HB) }\end{array}$ \\
\hline On the tread surface HB & $342-385$ & 297 \\
\hline In the head HB & 369 & 322 \\
\hline In the web, not exceeding & 388 & 303 \\
\hline In the base, not exceeding & 388 & 316 \\
\hline
\end{tabular}

It was found from the performed studies that the hardness of the tread surface of alumino-thermic welding of rail joints in a number of cases does not meet the required indicators of applicable technical standards. According to instructions for alumino-thermic welding of rails C-015, hardness of aluminothermic welded joints on the tread surface must be close to the hardness of quenched rails and reach the values 342-385 HB, while in the samples under examination hardness was $297 \mathrm{HB}$, being essentially below (45 HB) the permissible values. Hardness of the head of the exothermic welding joint is $322 \mathrm{HB}$, which is by $47 \mathrm{HB}$ below the permissible value specified in the applicable instruction C-015 [8]. Hardness of the welded seam is $303 \mathrm{HB}$, which is by $85 \mathrm{HB}$ below the standard. Nature of change in hardness of rail web in area of thermal impact is the same as in the welded joints of the rail 
head, while the structure of the welded joints of the rail web is coarser than in the rail head. Hardness in the area of the welded joints of the rail base is $316 \mathrm{HB}$, which is essentially below $(72 \mathrm{HB})$ the values of hardness of the welded joints in the head and web of the rail. Decreased hardness on the tread surface of the welded joints leads to uneven wear during their operation and is an underlying cause for crumbling of the rail head. The obtained results of hardness evaluation therefore indicate at a necessity to apply technical solutions such as grinding of rails by rail grinders that would remove the noticed shortcomings.

\section{Allumino-thermic welding rail chemical composition tested}

In the second part of the study in the Metallographic Laboratory of the Riga Technical University the chemical composition of metal in three points of the allumino-thermic welded joint (head, web, base) was analysed. The exothermic welding joint was cut out from two welded rails with a railcutting circular saw. Afterwards, the sample was polished with a sander, reaching a mirror-like surface, Fig. 5 [9]. The chemical composition of the metal was determined with the optical emission spectrometer PMI-Master PRO, operating according to the principle of local burning of the sample's surface followed by determination of the chemical composition and transfer of the obtained data to a printing device. Measuring was done three times in three different points: in the head, web and base of a counter-rail [10]. The average results of the analysis of the chemical composition of the samples are shown in Table 2.

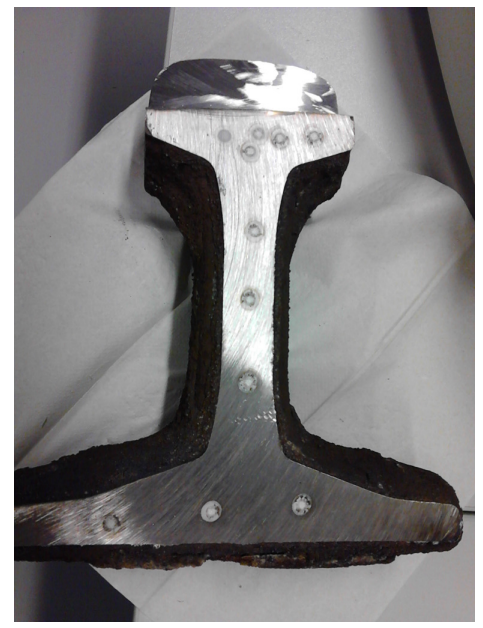

Fig. 5. Determination of chemical composition of ground exothermic welding joint: head, web, base

Table 2

Average and permissible values of chemical composition in \% in comparison to a study of ground exothermic welded joint (head, web, base) profile 60 E1 T IV 06

\begin{tabular}{|c|c|c|c|c|c|c|c|c|c|}
\hline Value & $\mathbf{F e}$ & $\mathbf{C}$ & $\mathbf{S i}$ & $\mathbf{M n}$ & $\mathbf{P}$ & $\mathbf{S}$ & $\mathbf{C r}$ & $\mathbf{M o}$ & $\mathbf{N i}$ \\
\hline Max / Min & - & \pm 0.02 & \pm 0.02 & \pm 0.05 & +0.005 & +0.005 & \pm 0.02 & - & - \\
\hline Head & 97.7 & 0.708 & 0.401 & 1.04 & 0.0050 & 0.0050 & 0.0529 & 0.0030 & 0.0080 \\
\hline Web & 97.6 & 0.711 & 0.424 & 1.07 & 0.0050 & 0.0050 & 0.0523 & 0.0030 & 0.0072 \\
\hline Base & 97.6 & 0.706 & 0.427 & 1.08 & 0.0050 & 0.0050 & 0.0547 & 0.0030 & 0.0088 \\
\hline Average & 97.6 & 0.708 & 0.417 & 1.06 & 0.0050 & 0.0050 & 0.0533 & 0.0030 & 0.0080 \\
\hline
\end{tabular}

\begin{tabular}{|c|c|c|c|c|c|c|c|c|c|}
\hline Value & $\mathbf{A l}$ & $\mathbf{C o}$ & $\mathbf{C u}$ & $\mathbf{N b}$ & $\mathbf{T i}$ & $\mathbf{V}$ & $\mathbf{W}$ & $\mathbf{P b}$ & $\mathbf{Z r}$ \\
\hline Max / Min & +0.001 & - & - & - & - & +0.02 & - & - & - \\
\hline Head & 0.0020 & 0.0052 & 0.0199 & 0.0030 & 0.0020 & 0.0035 & 0.0250 & 0.0100 & 0.0030 \\
\hline Web & 0.0020 & 0.0050 & 0.0217 & 0.0030 & 0.0020 & 0.0037 & 0.0250 & 0.0100 & 0.0030 \\
\hline Base & 0.0037 & 0.0050 & 0.0221 & 0.0030 & 0.0020 & 0.0040 & 0.0250 & 0.0100 & 0.0030 \\
\hline Average & 0.0026 & 0.0051 & 0.0212 & 0.0030 & 0.0020 & 0.0037 & 0.0250 & 0.0100 & 0.0030 \\
\hline
\end{tabular}


Table 3 shows the passport data concerning the chemical composition, provided by the factory of the manufacturer in Tagil [6].

Average statistical data obtained during studies were processed to make an accurate chemical analysis. Chemical analysis was performed along three points of the exothermic welding joint (head, web, base) under examination. Let us compare the data obtained with the data under the standard EN 13674:2004 [11], provided by the manufacturer, see Table 3 .

Table of average values of chemical composition of counter-rail profile

Table 3 $60 \mathrm{E} 1 \mathrm{~T}$ provided by Tagil factory

\begin{tabular}{|c|c|c|c|c|c|c|}
\hline Value & $\mathbf{C}$ & $\mathbf{N}$ & $\mathbf{V}$ & $\mathbf{S i}$ & $\mathbf{M n}$ & $\mathbf{P}$ \\
\hline Max / Min & \pm 0.02 & \pm 0.005 & 0.02 & \pm 0.02 & \pm 0.05 & +0.005 \\
\hline Average & 0.766 & 0.00457 & 0.0393 & 0.360 & 0.936 & 0.011 \\
\hline
\end{tabular}

\begin{tabular}{|c|c|c|c|c|c|}
\hline Value & S & Al & $\mathbf{C u}$ & $\mathbf{C r}$ & $\mathbf{N i}$ \\
\hline Max / Min & +0.005 & +0.001 & - & \pm 0.02 & - \\
\hline Average & 0.010 & 0.0026 & 0.0083 & 0.0367 & 0.0483 \\
\hline
\end{tabular}

Over a course of similar determination of chemical composition of the steel in an exothermic welding joint, performed in a lab of the Riga Technical University, the following discrepancies were detected. The following chemical elements are not specified in the data of the passport issued by the manufacturer: (Mo) Molybdenum, (Co) Cobalt, (Nb) Niobium, (Ti) Titanium, (V) Vanadium, (W) Wolfram, $(\mathrm{Pb})$ Lead, $(\mathrm{Zr})$ Zirconium. These chemical elements have essential impact on the quality of a welded joint and allow providing a thorough analysis of the quality of the manufactured product during the guarantee period and after it and also the operating costs. When establishing the main, permissible values of the chemical elements present in the rail steel (Tables 2,3), one can arrive at the following main conclusions about meeting the quality criteria of an exothermic welding joint: carbon (C) content is by $0.038 \%$ less than shown in the passport document issued by the manufacturer. Content of chemical element silicon ( $\mathrm{Si}$ ) is decreased by $0.037 \%$ [12]. Over the course of the tests their results show that manganese $(\mathrm{Mn})$ content is decreased by $0.042 \%$. Percentage composition of harmful admixtures such as phosphorous $(\mathrm{P})$ is decreased at $0.0060 \%$, and also content of sulphur (S) is decreased by $0.0050 \%$. Aluminium $(\mathrm{Al})$ content matches the data provided by the manufacturer and amounts to $0.0026 \%$. Chromium $(\mathrm{Cr})$ content lies in the permissible range and amounts to $0.0533 \%$.

\section{Materials and welding rail structure}

In the third part of the study the structure of rail steel of the exothermic welding joint was determined by means of a modern electronic microscope Carl Zeiss Axiovert 40 MAT, and the data were transferred to the computer. In the modern chemical laboratory of the Riga Technical University before determination of the metal structure the surface of the sample was corroded with $5 \%$ solution of nitric acid $\mathrm{HNO}_{3}$ [13]. Metal structure of the first sample was determined under a microscope at (x200) magnification without corroding the metal. The second sample had (x500) magnification and the metal was corroded.

The images obtained in the examination are shown in Fig. 6 a), b). One can draw the main conclusions from the results obtained concerning the quality of the exothermic welding joint. Inclusions appearing as black spots are found in the metal structure. One can assume that these are residuals of black grains (iron scale) that have not melted completely in a reaction of thermite joint formation. Phosphorous and sulphur content in the given chemical composition complies with the established range.

Microstructural analysis showed that the structure of the welded seam of the rail head, shown in Fig. 6 b), makes a coarse-grained structure, meaning that this area adjacent to the welding area was overheated and the large grains of austenite resulted in formation of lamellar pearlite with a ferrite network. Large-grained structure usually has lower plasticity and impact resistance. Lower impact resistance has an adverse impact on durability of metal leading to brittle fracture. 
a)

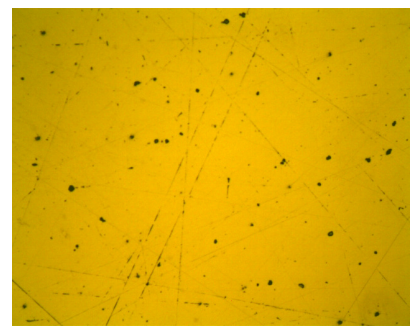

b)

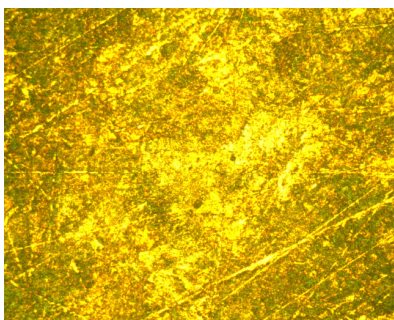

Fig. 6. Metal structure in polished exothermic welding joint under microscope at X200 magnification (a); metal structure in polished exothermic welding joint under microscope after corrosion with nitric acid (HN03) at X500 magnification (b)

\section{Results and discussion}

For the first time on the Latvian Railway in the Laboratories of the Riga Technical University the given results of tests in the area of exothermic welding joints were obtained, and grinding with the "Speno" rail grinder allows evaluating the condition and efficiency of the method of "trail" grinding with the lace of a cup wheel pattern and also shows the use of this method in countries such as the USA, England, France, and Germany. Hardness of the exothermic welding joint was determined in line with the applicable instruction C-015. Data of hardness in the thermite joint in the head, web and base have poor values and discrepancies with the technical standards specified in the instruction $\mathbf{C}$ 015, thus indicating at poor quality of the exothermic welding joint. Results of the study are true, since they were double-checked with a modern hardness tester "Tinius O Olsen" Fikrmware Version 1.07, FH-31 Series, confirming the obtained results in line with the standards ISO 6508 and ISO 2039/1. Chemical composition was determined with an optical emission spectrometer PMI-Master PRO, calibrated and tested on analogous samples of welded joints. The following was established during the tests: content of main chemical elements such as Al, S, P, Cr meets the standard EN 136741:2011, with reduced mass fractions of $\mathrm{C}$ and $\mathrm{Mn}$. Structure of the exothermic welding joint is largegrained in the welded area, because the area adjacent to the welding area was overheated and the large grains of austenite led to

formation of lamellar pearlite with a ferrite network featuring inclusion of dark spots. Perhaps, these are residuals of black spots (iron scale). Residuals of such elements can facilitate development of a defect and fracture in an exothermic welding joint.

\section{Conclusions}

1. Analysis of the diagram in Fig. 3 of the Latvian railway between 2014 and 2018 allows us concluding the following: total length of ground rails was $713.759 \mathrm{~km}$ of track, and average statistical grinding of rails per year during the given period was $142.752 \mathrm{~km}$ of track. And it is only one twenty-first of the entire length of the Latvian railway spreading as far as $3.017 \mathrm{~km}$. Accordingly, it proves one more time that it is more resource-effective for the Latvian railway to order grinding rather that have a rail grinder of its own.

2. The following conclusions can be drawn from the hardness tests performed on the exothermic welding joint: decreased hardness in the tread surface is $297 \mathrm{HB}$, which is by $45 \mathrm{HB}$ lower than the permissible values. Lowered hardness in the rail head can lead to uneven wear during the operation and can be a cause of crumbling of the rail head. Hardness in the head of the exothermic welding joint is $322 \mathrm{HB}$, which is by $47 \mathrm{HB}$ less than the permissible value under the applicable instruction C-105. Hardness in the rail web is $303 \mathrm{HB}$, which is by $85 \mathrm{HB}$ less than the claimed one. In the area of welded seams the rail base hardness is $316 \mathrm{HB}$, which is by $72 \mathrm{HB}$ less than the claimed hardness of the base.

3. The present study of hardness of the exothermic welding joint proves a discrepancy with the established technical standards and requires a special attention, control and additional planned preventive measures to extend the lifespan of the element in said construction; therefore, grinding of said exothermic welding joint might be one of such measures.

4. Chemical composition of steel in the exothermic welding joint was determined with the optical emission spectrometer PMI-Master PRO, the obtained data were compared to the data of the Tagil 
standard EN 13674-1:2011, arriving at the following results: carbon (C) content was decreased by $0.038 \%$ in comparison to the passport document issued by the manufacturer. Content of chemical element silicon $(\mathrm{Si})$ is decreased by $0.037 \%$. Over the course of the tests their results show that manganese $(\mathrm{Mn})$ content is decreased by $0.042 \%$. Percentage composition of harmful admixtures such as phosphorous $(\mathrm{P})$ is decreased at $0.0060 \%$, and also content of sulphur $(\mathrm{S})$ is decreased by $0.0050 \%$. Aluminium $(\mathrm{Al})$ content matches the data provided by the manufacturer and amounts to $0.0026 \%$. Chromium $(\mathrm{Cr})$ content was found within the permissible range and amounted to $0.0533 \%$. In the given chemical composition an essential role is played by carbon (C) content as a decisive factor in hardness and durability of metal, and the same applies to manganese (Mn) that enables increasing of durability, viscosity and suppleness, as well as resistance to wear. Reduction of mass fractions of these chemical elements once more evidences reduction of hardness in given exothermic welding joint.

5. When examining the exothermic welding joint, inclusions were detected appearing as black spots. One can assume that presence of remains of black grains (iron scale) in an exothermic welding joint indicates at poor quality of metal. Examinations of the metal structure also support a reduced impact resistance that has an adverse impact on the resistance of metal to brittle fractures.

6. That way, the obtained results concerning determination of hardness of the exothermic welding joint, chemical composition and structure of the examined metal call for taking technical measures, such as periodical grinding of rails with rail grinders, leading to extension of the lifespan of the element in given structure (rail head). In our case grinding of a relevant exothermic welding joint during the period of operation proves a good quality work performed by the "Speno" rail grinder.

7. The research carried out in the field of ground thermite connection by the railgrinding train company "Speno" has practical application in the network of European railways and can serve as a recommendation for the railgrinding train URR-112.

\section{References}

[1] Chen W., Shihui L., Ziqiang X., Chang G., Weihua M. Research on Bogie Frame Lateral Instability of High-Speed Railway Vehicle. Hindawi Shock and Vibration Volume 2018, Article ID 8469143, $13 \mathrm{p}$.

[2] EN 13231-3:2012 Railway applications-Track- Acceptance of works-Part 3: Acceptance of reprofiling rails in track.

[3] EN ISO 9001, Quality management systems - Requirements.

[4] ЕВРА3. Form 3. Export. СДС ОПЖТ RU.В.0020 24.08.2011 г. Quality Certificate Nr. 3094. Rails type 60 E1 Section class Y.Straightness B. EN 13674-1:2011, TC 00186269-189-2012.

[5] Jagodkins M. Latvian railway SJSC Service of railway equipment. Confirmed Latvian railway SJSC First deputy of CEO Инструкция по Алюмино-Термитной Сварки Рельсов C-015. Riga, 2002, pp. 3-20.

[6] Jagodkins M. Latvian railway SJSC Service of railway equipment. Confirmed Latvian railway SJSC First deputy of CEO Дефектам рельсов, их признакам, класификаций, католога, маркировки, и условий пропуска поездов по дефектным и остро-дефектным рельсам С-010. Riga, 2017, pp. 3-69.

[7] Korostelev P.P. Reagents for technical analysis, 1988, 104 p.

[8] Mihailovs S., Zaicevs D. Анализ факторов влияющих на изломы рельсов сваренных термитной сваркой (Analysis of factors affecting fractures of rails welded by thermite welding). No: V Международная научно-практическая конференция „Trans-Mech-Art-Chem”, Russia, Moscow, 23-26 April, 2007. Москва: МИИТ, 2008, 105.-106.lpp. ISBN 978-5-7876-0129-9. (In Russian).

[9] Stuart L., Grassie B. MIMechE, FPWI, Stuart Grassie Engineering Ltd. Studs and squats: A best practice approach. TECHNICAL ARTICLE AS PUBLISHED IN The Journal January 2018 Volume 136 Part 1. Also Procs of 10th Intnl Conference on Contact Mechanics and Wear of Rail/Wheel Systems, Colorado Springs, USA, August 2015Wear, vol 366-367, pp194-199, 2016. (In USA).

[10] Sergejevs D., Mihailovs S. Alumīnija-termiskā metināšanas metināto sliedes lūzumu ietekmējošo faktoru analīze (Analysis of Factors Affecting Fractures of Rails Welded by Alumino-Thermic 
Welding). No: LogiTrans : logistyka, systemy transportowe, bezpieczeństwo w transporcie : V konferencja naukowo-techniczna, Poland, Szczyrk, 23-25 April 2008. Radom: Politechnika Radomska, Wydawnictwo, 2008, 130.-131.p. (In Latvian).

[11] Strautmanis G., Mezītis M., Strautmane V., Gorbenko A. Vertikālā rotora modelis ar automātisku balansētāju ar divām kompensējošām masām (Model of a Vertical Rotor with an Automatic Balancer with Two Compensating Masses). Vibroengineering PROCEDIA, 2018, Vol.21, 202.207.lpp. ISSN 2345-0533. e-ISSN 2538-8479. Pieejams: doi:10.21595/vp.2018.20105. (In Latvian).

[12] Strautmanis G., Mezītis M., Strautmane V., Gorbenko A. Par rotora elastīgās piekares anizotropijas ietekmi uz automātiskā balansētāja darbību.(On the Issue of Impact of Anisotropy of the Rotor Elastic Suspension on the Performance of the Automatic Balancer). Vibroengineering Procedia, 2018, Vol.17, 1.-6.lpp. ISSN 2345-0533. Pieejams: doi:10.21595/vp.2018.19603. (In Latvian).

[13] Tatarinovs A., Mironovs V., Rybak D., Stankēvičs P. Detaļu savienojumu nesagraujošā kontrolē pārbaude ar pulsējošu magnētisko deformāciju (Non-Destructive Testing of Joints of Antifriction Parts Crimped by Pulsed Magnetic Deformation). Solid State Phenomena, 2017, Vol.267,. ISSN 1662-9779. Accessed via: doi:10.4028/www.scientific.ne. pp. 248-252. (In Latvian). 